\title{
Improving Students' Mathematical Representation and Critical Thinking Abilities Using the CAKA Media Based on Local Wisdom
}

\author{
https://doi.org/10.3991/ijim.v15i02.11355 \\ Heribertus Didik Kurniawan, Heru Kuswanto ${ }^{(凶)}$ \\ Yogyakarta State University, Yogyakarta, Indonesia \\ herukus61@uny.ac.id
}

\begin{abstract}
This study aims to develop a learning media based on the local wisdom of becak (pedicab) assisted by the Android to improve the mathematical representation and critical thinking abilities. It used the 4D model. The data were collected using a written test, and analysed by using the analysis of the gain scores. The result shows that the developed media based on the local wisdom of pedicab assisted by the Android (CAKA) is in a very good category and can be used as a learning media. The CAKA media can improve the mathematical representation and critical thinking abilities of grade $\mathrm{X}$ students of senior high school.
\end{abstract}

Keywords-Android, critical thinking, mathematical representation, mobile learning, pedicab

\section{Introduction}

The rapid development of technology in the 21 st century has resulted in varieties of inventions which facilitate human activities [1]. These inventions bring about adoption of innovation in various aspects of human life [2]. This has impacts on human way of life [2]. One of them is the use of computer technology in communication devices like smartphones. This change has also started to enter the education domain. The change that occurs in the education domain is known as mobile learning [3]. The term mobile learning (m-learning) refers to the use of information technology, such as mobile phone, laptop, tablet, and PC. The use of information technology will affect learning achievement and every device will have different effects [4]. M-learning as an innovation in teaching enables teaching processes to be more flexible and not to be stuck on the teaching which is dominantly oriented to teachers (teacher-centered), but learning can be done individually by students (student-centered). This makes it possible for learning to be done anywhere and anytime [5]-[7].

Learning that uses technology-based media has a significant effect on students. The use of such media stimulates students to learn. The use of technology can create a more interesting and enjoyable learning and learning atmosphere. This has impacts on students' learning achievement [8]. The use of technology-based media in teaching 
processes provides many facilities and utilities, although in its implementation constraints may occur. One of the possible constraints is the lack of technology-based medias which are suitable with teaching materials in school, especially in the teaching of physics. Another problem that often happens is the Internet connection when online medias are being used; not all schools have good Internet connection, and thus constraints will occur when online medias are being used [9], [10].

The more and more advanced technology enables the society to get unlimited information. This brings about the change of culture into modern society, so that they forget cultural bases they have inherited from their forefathers [11]. The integration of local wisdom in school instruction is one of the ways to make the people not lose their national self-identity. Education in school may not ignore local wisdom [12], [13]. The combination of local wisdom and science knowledge is very important in teaching. The local wisdom integrated in teaching can improve the teaching quality. This makes physics learning become more meaningful for students. Local wisdom-based teaching will also improve students' learning achievement [14].

In physics learning, there are many abilities needed by the students in order to solve physics problems. The representation and critical thinking abilities are examples of abilities needed by the students for solving a physics problem [15]. Representation in the teaching of physics is fundamental issue. The use and choice of an accurate representation format will help students to solve physics problems [16]. Mathematical representation ability of the students of some high schools in Indonesia is in the medium or even low category [17], [18]. Therefore, a solution is needed in order that the students' mathematical representation ability improves. An example of the solution that can be made is by administering practice tests and the teaching that trains students' mathematical representation ability. Like the mathematical representation ability, the critical thinking ability is also badly needed by students. This ability can help students analyse a problem and help them solve it. Empirical evidence shows that students' critical thinking ability is still in a low category [19].

Based on the problems above, a media that can facilitate physics learning in school is needed. Not only will it facilitate learning in school, it will also be expected to improve students' mathematical representation and critical thinking abilities. It is also expected to integrate the elements of local wisdom which can develop the students' knowledge of their local culture. This article will describe the steps taken in developing a local wisdom-based learning media which is practical and can be used offline and online and which can also improve the mathematical representation and critical thinking abilities of high school students.

\section{$2 \quad$ Literature Review}

\subsection{Mobile learning}

M-learning is the learning activity that uses a mobile media which enables students to access information and learning materials anytime and anywhere [20]. By using mlearning, students have freedom to choose when and where learning will be done. It 
also gives freedom to access information and learning materials which can improve the quality of their life regardless of their domicile, social status, and culture [21]. Its example is the use of smartphone in learning processes [3]. Its application in learning, particularly by using a smartphone or Android, can improve students' learning ability [22], [23]

The teaching content of m-learning consists of various kinds. It is highly related to the capacity of the device to display and operate. These various kinds of content require the programmer to make the content which is accurate and suitable with the characteristics of the device and users. Another important thing in m-learning is that not all content of conventional teaching can be transformed to the m-learning content. The content that can be presented in a device is texts, pictures, video, audio, and software application. There are three functions of m-learning in classroom instruction: Supplementary materials, which are optional; complementary materials; substitution materials [5].

Nowadays, Android is very popular in the society. Most people use it. There are some factors that make it very popular in the society, among others is the ease in using its application. In addition, Android application is also flexible to use [24]. The process of making Android application is very easy, so that it can be made suitable for the users' needs. Android application can help all kinds of human's activities, including education. The use of Android application smartphone is one of the examples of m-learning. The use of Android in teaching processes gives some benefits. In addition to giving benefits to learning which can be done anytime and anywhere, the use of Android in education, for example m-learning also gives very important benefits, i.e. students can control their own learning pace by themselves, because their ability to understand learning materials is different from one another [25]. This is very important to note because it will make students understand learning materials better and in the long run it will improve their learning achievement [26].

\section{$3 \quad$ Mathematical Representation and Critical Thinking Abilities}

Representation is human's ability to construct something which has been seen in the form of symbols [27]. Mathematical representation ability is the ability to construct a problem into a symbolic form or mathematical equation. Students' mathematical representation ability is related to physics teaching. The students who have a good mathematical representation ability will find it easy to explain the symbols found in physics. This will have effects on the way the students determine the physics equations they have to use and the way they work out the determined equations [28].

Thinking critically is a process that must be done to analyse the facts being faced and to result in an idea or opinion [29]. In science, thinking critically can be defined as the ability to obtain relevant and reliable knowledge about the universe. The knowledge is obtained through a set of systematic hypothesis testing, until a correct conclusion is obtained. The characteristic of critically thinking people is that they use their logic in drawing conclusions, understanding the differences between reasoning and rationality, and using facts intelligently and honestly [30]. 


\section{$4 \quad$ Local Wisdom of Pedicab}

Local wisdom is often called local policy, local knowledge, or local genius. In general, local wisdom is defined as a way of life and knowledge as well as various strategies of life which is realized in the activities done by the local community in solving various problems in order to satisfy their needs, including all aspects of life such as religion, economy, technology, social organization, language, and arts. Local wisdom can also be in the form of tradition, proverbs, wise words, or life mottos. The positive values of the local wisdom are potentials and basic capitals in building the selfidentity and national character [12], [31].

The pedicab is one of the forms of Indonesian local wisdom. It is a means of land transportation that has three wheels moved by manpower. It was very much used before World War II [32]. This vehicle is a modification of a bicycle. It is a very popular means of transportation in Indonesia. As a means of transportation, a pedicab is used not only for the mobility of the local people but also an attraction for foreign visitors. It is still maintained because it is a special attraction for tourists

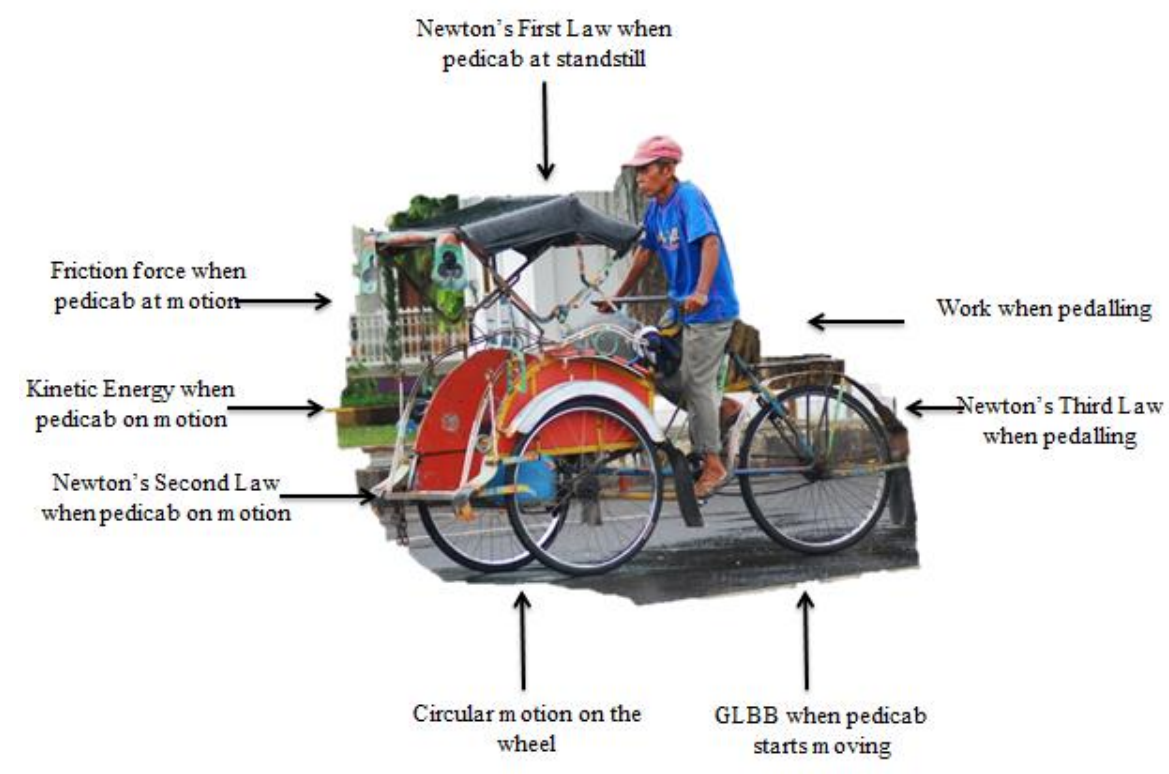

Fig. 1. Physics materials in pedicab

The pedicab can also be utilized as a part of a teaching process, especially in physics teaching. It can be used as an instructional media to understand some physics materials. By using a pedicab as learning media, the students are expected to find it easy to understand physics materials and apply them in their real life. The pedicab is analysed, and then physics materials are obtained (Figure 1), which can be learned through it. Some physics materials which can be learned through the use of pedicab include efforts and energy, Newton's Law, and circular motion. 


\section{$5 \quad$ Research Method}

This research is research and development (R\&D) using the 4D developmental model, which includes the stages of define, design, develop and disseminate [33]. The defining stage is the preliminary study where review of related theory and empirical review was done as detailed as possible. At this stage, the problem and the needs in teaching processes were defined so that it resulted in the idea of the media to be developed and needed in teaching. At the designing stage, the researcher designed the form and content of the media to be developed (idea) in its initial display, in the form of a storyboard. This initial display contains the layout of buttons, menu to be used, choice of animation to be used, main menu display, materials, evaluation and menu of developers' profiles and collection of material sources, animation, video, music, and the software used to make the learning media. The developing stage is the stage where the media began to be developed. All of the instruments used in the research were validated by experts. The suggestions and comments given were used as the inputs for the improvement of the learning media before it was used by practitioners. The disseminating stage is the final stage in this research. After the media had been improved through the revision process, it was disseminated in the form of application in Android mobile phones. The disseminating process was done in conferences, scientific journals, play store, teachers, and grade X science students of high schools.

This research was conducted at State Senior High School 3 Yogyakarta. The research sample was grade X students of MIA. The students were divided into two classes: The control class consisting of 35 students, and the experimental class consisting of 34 students. The research used the pretest-posttest control group design, as presented in Table 1.

Table 1. Pretests-Postest Control Group Design

\begin{tabular}{|c|l|c|c|c|}
\hline No. & \multicolumn{1}{|c|}{ Class } & Pretest & Treatment & Postest \\
\hline 1. & Experimental & $\mathrm{O}_{1}$ & $\mathrm{X}_{1}$ & $\mathrm{O}_{2}$ \\
\hline 2. & Control & $\mathrm{O}_{1}$ & $\mathrm{X}_{2}$ & $\mathrm{O}_{2}$ \\
\hline
\end{tabular}

Where,

$\mathrm{O} 1=$ Pretest

$\mathrm{O} 2=$ Postest

$\mathrm{X} 1=$ Using the CAKA Media

$\mathrm{X} 2$ = Not Using the CAKA Media

The improvement of the students' mathematical representation and critical thinking abilities was measured using the gain score. The gain score calculated using Equation (1), and the gain score criteria are presented in Table 2.

$$
g=\frac{S_{f}-S_{i}}{100-S_{i}}
$$

where $S_{\mathrm{f}}$ is the final score obtained in the posttest and $S_{i}$ is the initial score obtained in the pretest. 
Table 2. Criteria of gain score

\begin{tabular}{|c|c|c|}
\hline No. & Gain score & Criteria \\
\hline 1. & $\mathrm{~g} \geq 0.70$ & High \\
\hline 2. & $0.30 \leq \mathrm{g}<0.70$ & Medium \\
\hline 3 & $\mathrm{~g}<0.30$ & Low \\
\hline
\end{tabular}

\section{$6 \quad$ Result and Discussion}

\subsection{Basis of media development}

Based on the problems that arose and the research variables, a matrix which could become the guide for developing the learning media was constructed. The matrix helped the researcher determine the form and parts of the developed media. The matrix contained the indicators of the mathematical representation and critical thinking abilities, and any physics materials which can be learned using the pedicab and which were put in the media. The matrix also contained the objectives and targets that the students had to be able to do. The matrix of the learning media is presented in Table 3 , Table 4 and Table 5 .

Table 3. Matrix of learning media on Effort and Energy materials

\begin{tabular}{|c|c|c|c|c|}
\hline \multirow{2}{*}{ Indicator } & \multicolumn{4}{|c|}{ Effort and Energy } \\
\hline & Efforts & Kinetics & Potensial & Mechanical \\
\hline Inferencing & $\begin{array}{l}\text { Selecting true factual } \\
\text { statements on efforts }\end{array}$ & $\begin{array}{l}\text { Selecting true factual } \\
\text { statements on kinetics } \\
\text { energy }\end{array}$ & \begin{tabular}{|l|} 
Selecting true factual \\
statements on \\
potensial energy
\end{tabular} & $\begin{array}{l}\text { Selecting true factual } \\
\text { statements on } \\
\text { mechanical energy }\end{array}$ \\
\hline $\begin{array}{l}\text { Analysing } \\
\text { Assumption }\end{array}$ & $\begin{array}{l}\text { Making decision from } \\
\text { some assumptions of } \\
\text { efforts }\end{array}$ & $\begin{array}{l}\text { Making decision from } \\
\text { some assumptions of } \\
\text { kinetics energy }\end{array}$ & $\begin{array}{l}\text { Making decision } \\
\text { from some assump- } \\
\text { tions of potensial } \\
\text { energy }\end{array}$ & $\begin{array}{l}\text { Making decision } \\
\text { from some assump- } \\
\text { tions of mechanical } \\
\text { energy }\end{array}$ \\
\hline Deducting & $\begin{array}{l}\text { Making conclusions of } \\
\text { efforts }\end{array}$ & $\begin{array}{l}\text { Making conclusions of } \\
\text { kinetic energy }\end{array}$ & $\begin{array}{l}\text { Making conclusions } \\
\text { of potensial energy }\end{array}$ & $\begin{array}{l}\text { Making conclusions } \\
\text { of mechanical energy }\end{array}$ \\
\hline Interpreting & $\begin{array}{l}\text { Concluding logically } \\
\text { based on information } \\
\text { of efforts }\end{array}$ & $\begin{array}{l}\text { Concluding logically } \\
\text { based on information } \\
\text { of kinetic energy }\end{array}$ & $\begin{array}{l}\text { Concluding logically } \\
\text { based on information } \\
\text { of potensial energy }\end{array}$ & $\begin{array}{l}\text { Concluding logically } \\
\text { based on information } \\
\text { of mechanical energy }\end{array}$ \\
\hline $\begin{array}{l}\text { Evaluating } \\
\text { Argument }\end{array}$ & $\begin{array}{l}\text { Evaluating if the } \\
\text { argument of efforts is } \\
\text { strong or weak }\end{array}$ & $\begin{array}{l}\text { Evaluating if the } \\
\text { argument of kinetics } \\
\text { energy is strong or } \\
\text { weak }\end{array}$ & $\begin{array}{l}\text { Evaluating if the } \\
\text { argument of potensial } \\
\text { energy is strong or } \\
\text { weak }\end{array}$ & $\begin{array}{l}\text { Evaluating if the } \\
\text { argument of } \\
\text { mechanical energy is } \\
\text { strong or weak }\end{array}$ \\
\hline $\begin{array}{l}\text { Determining } \\
\text { correct equa- } \\
\text { tion based on } \\
\text { problems }\end{array}$ & $\begin{array}{l}\text { Determining correct } \\
\text { equation according to } \\
\text { efforts problems }\end{array}$ & $\begin{array}{l}\text { Determining correct } \\
\text { equation according to } \\
\text { kinetics energy prob- } \\
\text { lems }\end{array}$ & $\begin{array}{l}\text { Determining correct } \\
\text { equation according to } \\
\text { potensial energy } \\
\text { problems }\end{array}$ & $\begin{array}{l}\text { Determining correct } \\
\text { equation according to } \\
\text { mechanical energy } \\
\text { problems }\end{array}$ \\
\hline $\begin{array}{l}\text { Operating } \\
\text { mathematical } \\
\text { equation to } \\
\text { solve prob- } \\
\text { lems }\end{array}$ & $\begin{array}{l}\text { Operating mathemati- } \\
\text { cal equation to solve } \\
\text { problems on efforts }\end{array}$ & $\begin{array}{l}\text { Operating mathemati- } \\
\text { cal equation to solve } \\
\text { problems on kinetics } \\
\text { energy }\end{array}$ & $\begin{array}{l}\text { Operating mathemat- } \\
\text { ical equation to solve } \\
\text { problems on } \\
\text { potensial energy }\end{array}$ & $\begin{array}{l}\text { Operating mathemat- } \\
\text { ical equation to solve } \\
\text { problems on } \\
\text { mechanical energy }\end{array}$ \\
\hline
\end{tabular}


Paper-Improving Students' Mathematical Representation and Critical Thinking Abilities Using the...

Table 4. Matrix of learning media on Newton Law materials.

\begin{tabular}{|l|l|l|}
\hline \multirow{2}{*}{\multicolumn{1}{|c|}{ Indicator }} & \multicolumn{1}{c|}{ Newton Law } \\
\cline { 2 - 3 } Inferencing & \multicolumn{1}{|c|}{\begin{tabular}{c}
\multicolumn{1}{c|}{ Newton's First Law } \\
Nelecting true factual statements on
\end{tabular}} & $\begin{array}{l}\text { Selecting true factual statements on } \\
\text { Newton's Second Law }\end{array}$ \\
\hline $\begin{array}{l}\text { Analysing Assump- } \\
\text { tions }\end{array}$ & $\begin{array}{l}\text { Making decision from some Assump- } \\
\text { tions of Newton's First Law }\end{array}$ & $\begin{array}{l}\text { Making decision from some Assump- } \\
\text { tions of Newton's Second Law }\end{array}$ \\
\hline Deducting & $\begin{array}{l}\text { Making conclusions of Newton's First } \\
\text { Law }\end{array}$ & $\begin{array}{l}\text { Making conclusions of Newton's Second } \\
\text { Law }\end{array}$ \\
\hline Interpreting & $\begin{array}{l}\text { Concluding logically based on infor- } \\
\text { mation of Newton's First Law }\end{array}$ & $\begin{array}{l}\text { Concluding logically based on infor- } \\
\text { mation of Newton's Second Law }\end{array}$ \\
\hline $\begin{array}{l}\text { Evaluating Arguments } \\
\text { Fvaluating if the argument of Newton's } \\
\text { First Law is strong or weak }\end{array}$ & $\begin{array}{l}\text { Evaluating if the argument of Newton's } \\
\text { Second Law is strong or weak }\end{array}$ \\
\hline $\begin{array}{l}\text { Determining correct } \\
\text { equation based on } \\
\text { problems }\end{array}$ & $\begin{array}{l}\text { Determining correct equation according } \\
\text { to Newton's First Law problems }\end{array}$ & $\begin{array}{l}\text { Determining correct equation according } \\
\text { to Newton's Second Law problems }\end{array}$ \\
\hline $\begin{array}{l}\text { Operating mathemati- } \\
\text { cal equation to solve } \\
\text { problems }\end{array}$ & $\begin{array}{l}\text { Operating mathematical equation to } \\
\text { solve problems on Newton's First Law }\end{array}$ & $\begin{array}{l}\text { Operating mathematical equation to } \\
\text { solve problems on Newton's Second } \\
\text { Law }\end{array}$ \\
\hline
\end{tabular}

\subsection{Media}

The learning media was developed using the 4D model. It consists of competencies, materials, simulation, and practice tests. It is the learning realized in the form of materials, test, quiz and other ways of learning through network [34]. This media is named CAKA. It is the physics learning media which contains the materials on efforts and energy, Newton's Law, and circular motion. It includes the element of local wisdom, i.e., pedicab, which is used as the learning aid to understand physics materials. Through the use of the pedicab, some physics materials such as efforts and energy, Newton's Law, and circular motion can be learned. Figures 2, 3, and 4 show the samples of media.

Table 5. Learning media matrix with Circular Motion.

\begin{tabular}{|c|c|c|c|c|}
\hline \multirow{2}{*}{ Indicator } & \multicolumn{4}{|c|}{ Circular Motion } \\
\hline & Period & Frequency & Linear Velocity & Angular Velocity \\
\hline Inferencing & $\begin{array}{l}\text { Selecting true factual } \\
\text { statements on Period }\end{array}$ & $\begin{array}{l}\text { Selecting true } \\
\text { factual statements } \\
\text { on frequency }\end{array}$ & $\begin{array}{l}\text { Selecting true factual } \\
\text { statements on linear } \\
\text { velocity }\end{array}$ & $\begin{array}{l}\text { Selecting true factual } \\
\text { statements on angular } \\
\text { velocity }\end{array}$ \\
\hline $\begin{array}{l}\text { Analysing } \\
\text { Assumption }\end{array}$ & $\begin{array}{l}\text { Making decision } \\
\text { from some Assump- } \\
\text { tions of Period }\end{array}$ & $\begin{array}{l}\text { Making decision } \\
\text { from some Assump- } \\
\text { tions of frequency }\end{array}$ & $\begin{array}{l}\text { Making decision } \\
\text { from some Assump- } \\
\text { tions of linear } \\
\text { velocity }\end{array}$ & $\begin{array}{l}\text { Making decision } \\
\text { from some Assump- } \\
\text { tions of angular } \\
\text { velocity }\end{array}$ \\
\hline Deducting & $\begin{array}{l}\text { Making conclusions } \\
\text { of Period }\end{array}$ & $\begin{array}{l}\text { Making conclusions } \\
\text { of frequency }\end{array}$ & $\begin{array}{l}\text { Making conclusions } \\
\text { of linear velocity }\end{array}$ & $\begin{array}{l}\text { Making conclusions } \\
\text { of angular velocity }\end{array}$ \\
\hline Interpreting & $\begin{array}{l}\text { Concluding logically } \\
\text { based on information } \\
\text { of Period }\end{array}$ & $\begin{array}{l}\text { Concluding logical- } \\
\text { ly based on infor- } \\
\text { mation of frequency }\end{array}$ & $\begin{array}{l}\text { Concluding logically } \\
\text { based on information } \\
\text { of linear velocity }\end{array}$ & $\begin{array}{l}\text { Concluding logically } \\
\text { based on information } \\
\text { of angular velocity }\end{array}$ \\
\hline $\begin{array}{l}\text { Evaluating argu- } \\
\text { ments }\end{array}$ & $\begin{array}{l}\text { Evaluating if the } \\
\text { argument of Period is } \\
\text { strong or weak }\end{array}$ & $\begin{array}{l}\text { Evaluating if the } \\
\text { argument of } \\
\text { frequency is strong }\end{array}$ & $\begin{array}{l}\text { Evaluating if the } \\
\text { argument of linear } \\
\text { velocity is strong or }\end{array}$ & $\begin{array}{l}\text { Evaluating if the } \\
\text { argument of angular } \\
\text { velocity is strong or }\end{array}$ \\
\hline
\end{tabular}


Paper-Improving Students' Mathematical Representation and Critical Thinking Abilities Using the..

\begin{tabular}{|l|l|l|l|l|}
\hline & or weak & weak & weak \\
\hline $\begin{array}{l}\text { Determining } \\
\text { correct equation } \\
\text { based on problems }\end{array}$ & $\begin{array}{l}\text { Determining correct } \\
\text { equation according to } \\
\text { Period problems }\end{array}$ & $\begin{array}{l}\text { Determining correct } \\
\text { equation according } \\
\text { to frequency prob- } \\
\text { lems }\end{array}$ & $\begin{array}{l}\text { Determining correct } \\
\text { equation according to } \\
\text { linear velocity prob- } \\
\text { lems }\end{array}$ & $\begin{array}{l}\text { Determining correct } \\
\text { equation according to } \\
\text { angular velocity } \\
\text { problems }\end{array}$ \\
\hline $\begin{array}{l}\text { Operating mathe- } \\
\text { matical equation to } \\
\text { solve problems }\end{array}$ & $\begin{array}{l}\text { Operating mathemat- } \\
\text { ical equation to solve } \\
\text { problems on Period }\end{array}$ & $\begin{array}{l}\text { Operating mathe- } \\
\text { matical equation to } \\
\text { solve problems on } \\
\text { frequency }\end{array}$ & $\begin{array}{l}\text { Operating mathemat- } \\
\text { ical equation to solve } \\
\text { problems on linear } \\
\text { velocity }\end{array}$ & $\begin{array}{l}\text { Operating mathemat- } \\
\text { ical equation to solve } \\
\text { problems on angular } \\
\text { velocity }\end{array}$ \\
\hline
\end{tabular}

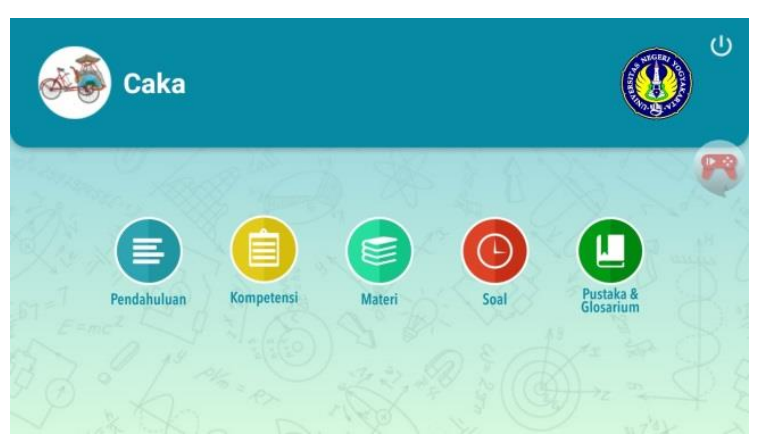

Fig. 2. Application Initial Display

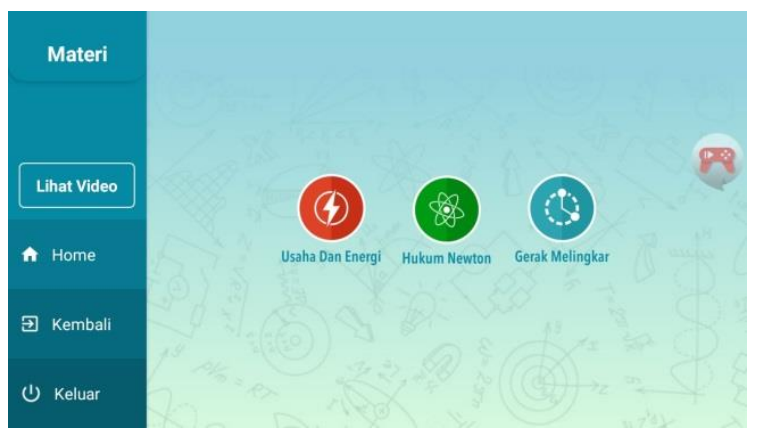

Fig. 3. Material Display

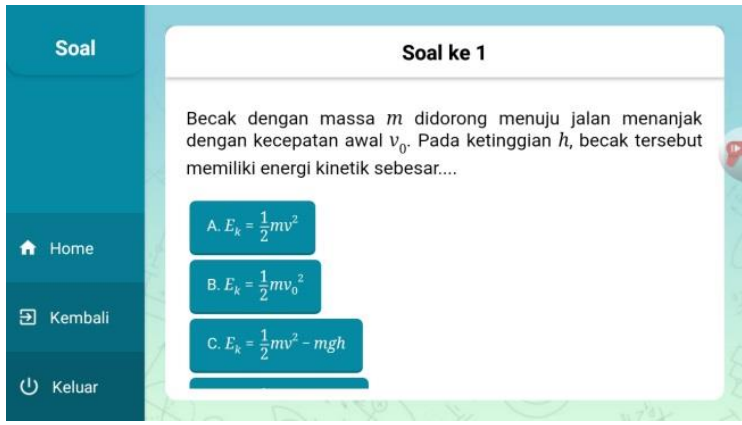

Fig. 4. Practice Test Display. 


\subsection{Media validation result}

CAKA application has gone through the validation by materials experts and media experts, and the evaluation by high school physics teachers and peer reviewers. The evaluation has also been done by high school students in the limited and field try-outs. In the aspects of materials and media, CAKA application is considered very good in terms of quality and suitability according to the evaluation done by experts, high school physics teachers and peer reviewers and it has good quality according to students. The result of the evaluation on the quality of the media in terms of the aspect of the software engineering and visual communication according to media experts, peer reviewers, and high school physics teachers is presented in Table 6.

Table 6. Result of Evaluation on Audio Visual Aspect and Software Technology

\begin{tabular}{|c|l|c|c|l|}
\hline No. & \multicolumn{1}{|c|}{ Aspects } & Total & Maximum Score & \multicolumn{1}{|c|}{ Category } \\
\hline 1. & Software Engineering & 34 & 36 & Very Good \\
\hline 2. & Visual Communication & 23 & 27 & Good \\
\hline \multicolumn{2}{|l|}{ Total } & 57 & 63 & Good \\
\hline
\end{tabular}

By converting the data on the result of the evaluation by media experts, peer reviewers, and physics teachers in the two aspects as the basis, the researcher found that the developed learning media was in the good category. The total score obtained for the two aspects is 57 (out of the maximum score of 63). The result of material experts and peer reviewers, and physics teachers' evaluation on the aspects of teaching and the content adequacy of the materials is presented in Table 7.

Table 7. Result of Evaluation on Teaching and Material Aspects by Material Experts, Peer Reviewer (PR) and Physics Teacher (PT).

\begin{tabular}{|c|l|c|c|l|}
\hline No. & \multicolumn{1}{|c|}{ Aspects } & Total & Highest Score & \multicolumn{1}{c|}{ Category } \\
\hline 1. & Teaching & 18 & 18 & Very Good \\
\hline 2. & Content/Material Adequacy & 26 & 27 & Very Good \\
\hline \multicolumn{2}{|c|}{ Total } & 44 & 45 & Very Good \\
\hline
\end{tabular}

From the result of the evaluation by materials experts, peer reviewers, and physics teachers on the learning media and materials aspects, the total score gained is 44 (out of the maximum score of 45). The total score ranges in the A category, which is very good. The evaluation of the media aspect involved 30 grade $\mathrm{X}$ students of high school. The aspects under evaluation are teaching and materials as well as the graphics and operation of the media. The result is presented in Table 8 .

Table 8. Result of Evaluation on Limited Try-out Media

\begin{tabular}{|c|l|c|c|l|}
\hline No. & \multicolumn{1}{|c|}{ Aspects } & Limited Test & Maximum Score & \multicolumn{1}{|c|}{ Category } \\
\hline 1. & Teaching/material & 14 & 16 & Good \\
\hline 2. & Operation and Navigation & 25 & 28 & Good \\
\hline 3. & Program Appeal & 15 & 16 & Very Good \\
\hline 4. & Program Utility & 7 & 8 & Very Good \\
\hline Total & 61 & 68 & Good \\
\hline
\end{tabular}




\subsection{The result of improving mathematical representation and critical thinking} abilities

The field try-out used the pretest-posttest group design, involving grade $\mathrm{X}$ students of MIPA 3 as the control class and those of MIPA 2 as the experimental class. This try-out aimed to see whether or not there were differences between learning by using Android-assisted media and that by using the traditional teaching which is often used by teachers in the school. Besides, it aimed to see whether the Android-assisted media could improve the students' mathematical representation and critical thinking abilities. The result of the pretest-posttest can be seen in Tables 9 and 10 .

Table 9. Result of Improving Students' Mathematical Representation Ability

\begin{tabular}{|c|l|c|c|c|c|l|}
\hline \multirow{2}{*}{ No } & \multirow{2}{*}{ Class } & \multirow{2}{*}{$\begin{array}{c}\text { Number of } \\
\text { Students }\end{array}$} & \multicolumn{2}{|c|}{$\begin{array}{c}\text { Average Mathematical } \\
\text { Representation }\end{array}$} & \multirow{2}{*}{$\begin{array}{c}\text { Average } \\
\text { n-gain }\end{array}$} & \multirow{2}{*}{ Category } \\
\cline { 4 - 5 } & & & Pretest & Posttest & & \\
\hline 1 & Experimental & 34 & 21.14 & 77.94 & 0.72 & High \\
\hline 2 & Control & 35 & 22.68 & 65.89 & 0.55 & Moderate \\
\hline
\end{tabular}

Table 10. Result of Improving Students' Critical Thinking Ability

\begin{tabular}{|c|c|c|c|c|c|c|}
\hline \multirow{2}{*}{ No } & \multirow{2}{*}{ Class } & \multirow{2}{*}{$\begin{array}{c}\text { Number of } \\
\text { Students }\end{array}$} & \multicolumn{2}{|c|}{ Critical Thinking Average } & \multirow{2}{*}{$\begin{array}{c}\text { Average } \\
\text { n-gain }\end{array}$} & \multirow{2}{*}{ Category } \\
\hline & & & Pretest & Posttest & & \\
\hline 1 & Experimental & 34 & 20.74 & 61.18 & 0.51 & Medium \\
\hline 2 & Control & 35 & 21.14 & 40.14 & 0.24 & Low \\
\hline
\end{tabular}

\subsection{The result of the test of the media effectiveness in improving mathematical} representation and critical thinking abilities

The effectiveness test is carried out by giving a question about the measurement of critical thinking ability and mathematical representation in each group (experimental class) in the pretest-posttest activity then the scores obtained by students in the pretest-posttest activity are analyzed using the ANAVA mix design. The ANAVA analysis was carried out to review the significance of the differences in each class. The ANAVA mix design analysis on general linear models used statistical analysis program. There are two hypothesis tests that must be done before the effectiveness test, namely the test for changes in the pretest-posttest score and the test to find out the increase in the pretest-posttest score in the experimental and control classes.

The results of the first hypothesis test show changes in the pretest-posttest score in the experimental and control classes. The changes in the pretest-posttest scores for the two classes are significantly different. The results of the second Hypothesis Test show an increase in scores. The biggest increase in the increase from pretest to posttest occurred in the experimental class that used the physics learning media, that is 56.801 in mathematical representation and an increase of -40.441 for critical thinking skills can be seen in Table 11 and Table 12. 
Table 11. Result of Pairwise Comparison for Testing the Second Hypothesis of Mathematical Representation Ability

\begin{tabular}{|l|c|c|c|c|c|}
\hline \multirow{2}{*}{ Class } & (I) Time & $(\mathbf{J})$ Ttime & $\begin{array}{c}\text { Mean Difference } \\
(\mathbf{I}-\mathbf{J})\end{array}$ & Std. Error & Sig. $^{\text {a }}$ \\
\hline \multirow{2}{*}{ Experimental } & 1 & 2 & $-56.801^{*}$ & 2.441 & .000 \\
\cline { 2 - 6 } & 2 & 1 & $56.801^{*}$ & 2.441 & .000 \\
\hline \multirow{2}{*}{ Control } & 1 & 2 & $-43.214^{*}$ & 2.406 & .000 \\
\cline { 2 - 6 } & 2 & 1 & $43.214^{*}$ & 2.406 & .000 \\
\hline
\end{tabular}

Table 12. Result of Pairwise Comparison for Testing the Second Hypothesis of Critical Thinking Ability

\begin{tabular}{|l|c|c|c|c|c|}
\hline \multirow{2}{*}{ Class } & (I) Time & (J) Time & $\begin{array}{c}\text { Mean Difference } \\
\text { (I-J) }\end{array}$ & Std. Error & Sig. $^{\text {a }}$ \\
\hline \multirow{2}{*}{ Experimental } & 1 & 2 & $-40.441^{*}$ & 2.390 & .000 \\
\cline { 2 - 6 } & 2 & 1 & $40.441^{*}$ & 2.390 & .000 \\
\hline \multirow{2}{*}{ Control } & 1 & 2 & $-19.000^{*}$ & 2.355 & .000 \\
\cline { 2 - 6 } & 2 & 1 & $19.000^{*}$ & 2.355 & .000 \\
\hline
\end{tabular}

The developed media effectiveness testing was conducted to find out the effectiveness (contributions) of the treatment given to each group. The effectiveness value can be seen in the effectiveness of the multivariate test column from the results of the ANAVA analysis by reviewing partial eta squared. The greatest partial eta squared value informs the effectiveness of the treatment done in the class in improving the critical thinking and mathematical representation abilities. Table 13 and Table 14 present the result of the comparison between the partial eta squared value in the experimental class and that in the control class on the mathematical representation and critical thinking abilities.

Table 13. Effectiveness Test Results of Mathematical Representation Ability

\begin{tabular}{|l|l|c|c|}
\hline \multicolumn{2}{|l|}{ Class } & Sig. & Partial Eta Squared \\
\hline \multirow{4}{*}{ Experimental } & Pillai's trace & .000 & .890 \\
\cline { 2 - 4 } & Wilks' lambda & .000 & .890 \\
\cline { 2 - 4 } & Hotelling's trace & .000 & .890 \\
\cline { 2 - 4 } & Roy's largest root & .000 & .890 \\
\hline \multirow{5}{*}{ Control } & Pillai's trace & .000 & .528 \\
\cline { 2 - 4 } & Wilks' lambda & .000 & .528 \\
\cline { 2 - 4 } & Hotelling's trace & .000 & .528 \\
\cline { 2 - 4 } & Roy's largest root & .000 & .528 \\
\hline
\end{tabular}


Paper-Improving Students' Mathematical Representation and Critical Thinking Abilities Using the...

Table 14. Effectiveness Test Results of Critical Thinking Ability

\begin{tabular}{|l|l|c|c|}
\hline \multicolumn{2}{|l|}{ Class } & Sig. & Partial Eta Squared \\
\hline \multirow{5}{*}{ Experimental } & Pillai's trace & .000 & .810 \\
\cline { 2 - 4 } & Wilks' lambda & .000 & .810 \\
\cline { 2 - 4 } & Hotelling's trace & .000 & .810 \\
\cline { 2 - 4 } & Roy's largest root & .000 & .810 \\
\hline \multirow{4}{*}{ Control } & Pillai's trace & .000 & .493 \\
\cline { 2 - 4 } & Wilks' lambda & .000 & .493 \\
\cline { 2 - 4 } & Hotelling's trace & .000 & .493 \\
\cline { 2 - 4 } & Roy's largest root & .000 & .493 \\
\hline
\end{tabular}

Table 13 shows the largest partial eta squared value in the mathematical representation ability to occur in the experimental class (using the developed physics learning media based on local pedicab wisdom with the help of Android). In Group 1 (experimental class) the developed media is effective in improving mathematical representation ability by 0.890 or $89 \%$. The value obtained by group 2 (control class) is 0.528 or $52.8 \%$.

Table 14 shows the largest partial eta squared value in the experimental class (using the developed physics learning media). The treatment given to the experimental class can increase the ability to think critically by 0.810 or $81.0 \%$ and for the control class, the partial eta squared value is 0.493 or $49.3 \%$.

\section{Discussion}

The CAKA learning media was developed based on the matrix shown in Table 1 and Table 2. In the matrix, there are the variables of mathematical representation and critical thinking abilities. The physics materials which can be learned through the pedicab are also included in the matrix. Through the matrix, the researchers can know the goals that have to be achieved by students. It helped the researchers to determine the content which can be used to improve students' mathematical representation and critical thinking abilities.

The CAKA learning media consists of some parts including: Competencies, materials, simulation, practice test, references, and glossaries. It contains three materials which students can learn: Efforts and energy, Newton's Law, and circular motion. Each material is accompanied with simulation which students can do in order to have deeper understanding of the available materials. There is also a video program containing the history of pedicabs and any physics materials which can be learned from pedicabs in addition to the presented materials. CAKA media also provides practice tests which students can do. The available test items are suitable with the criteria of mathematical representation and critical thinking abilities. When the students finished doing the practice test, their mathematical representation and critical thinking abilities have been improving.

The learning media developed using the 4D model is feasible to use by students, as shown by the good result of the validation done by materials experts, media experts, teachers, and peers. After the validation, a limited try-out was conducted through 
students' response questionnaire. The product validation in the aspects of materials and media shows that the developed media is in a very good category. The result of the limited try-out using students' response questionnaire shows that the developed media is in a very good category.

The CAKA media was applied in teaching processes, in which a pre-test and posttest were administered to students. The result of the pre-test and post-test was used to see the effect of the CAKA media on the students' mathematical representation and critical thinking abilities. The result of the analysis shows that there is a difference in the average gain score of the students in the control class and that of those in the experimental class. The average gain score in mathematical representation of the experimental class is 0.72 , which is in a high category, while that of the control class is 0.55 , which is in a medium category. This shows that the use of the CAKA media has a good impact on the students' mathematical representation ability. This also applies to the critical thinking ability. The average gain score of the experimental class is 0.51 , which is in the medium category. This score is higher than the score of the control class, i.e., 0.24, which is in the low category. That the use of local wisdom also has good impacts is in line with the research by Kurniawati [35] which reported that the teaching that integrates local wisdom can improve students' understanding and motivation. The students also like the local wisdom-based learning materials. This result is in line with the finding of the research by Abadi, Asih, and Jupri [36]. CAKA learning media is effective in increasing scores in the experimental class by $89 \%$ for mathematical representation abilities and $81 \%$ for critical thinking ability.

\section{Conclusion}

Based on the result of this research, it can be concluded that the CAKA media is feasible to use. This is based on the result of the validation by media experts, materials experts, physics teachers, and peer reviewers, resulting in the total score which is in a very good category. While the result of the limited try-out shows that the developed media is in a good category. The CAKA media also improves students' mathematical representation and critical thinking abilities, as shown by the gain score of the experimental class, which is higher than that of the control class.

\section{$9 \quad$ References}

[1] K. Ninaus, S. Diehl, R. Terlutter, K. Chan, and A. Huang, "Benefits and stressors - Perceived effects of ICT use on employee health and work stress: An exploratory study from Austria and Hong Kong," Int. J. Qual. Stud. Health Well-being, vol. 10, no. 1, p. 28838, Jan. 2015. https://doi.org/10.3402/qhw.v10.28838

[2] J. R. Beniger, The Control Revolution: Technological and Economic Origins of the Information Society. Massachusetts: Harvard University Press, 1946.

[3] K. T. Martono and O. D. Nurhayati, "Implementation of Android Based Mobile Learning Apllication as a Flexible Learning Media," Int. J. Comput. Sci. Issues, vol. 11, no. 3, pp. 168-174, 2014. 
[4] D. K. Yoo and S. Cho, "Role of Habit and Value Perceptions on m-Learning Outcomes," J. Comput. Inf. Syst., pp. 1-11, Dec. 2018.

[5] Y. Mehdipour and H. Zerehkafi, "Mobile Learning for Education: Benefits and Challenges,” Int. J. Comput. Eng. Res., vol. 03, no. 6, pp. 93-101, 2013.

[6] P. A. Ertmer and A. T. Ottenbreit-Leftwich, "Teacher technology change: How knowledge, confidence, beliefs, and culture intersect," J. Res. Technol. Educ., vol. 42, no. 3, pp. 255-284, Mar. 2010. https://doi.org/10.1080/15391523.2010.10782551

[7] M. M. Terras and J. Ramsay, "The five central psychological challenges facing effective mobile learning,” Br. J. Educ. Technol., vol. 43, no. 5, pp. 820-832, Sep. 2012. https://doi. org/10.1111/j.1467-8535.2012.01362.x

[8] A. A. Sakat, M. Z. Mohd Zin, R. Muhamad, A. Ahmad, N. A. Ahmad, and M. A. Kasmo, "Educational technology media method in teaching and learning progress," Am. J. Appl. Sci., vol. 9, no. 6, pp. 874-878, 2012.

[9] H. F. Hanafi and K. Samsudin, "Mobile Learning Environment System (MLES): The Case of Android-based Learning Application on Undergraduates' Learning," IJACSA) Int. J. Adv. Comput. Sci. Appl., vol. 3, no. 3, pp. 1-5, 2012. https://doi.org/10.14569/ijacsa.2012. $\underline{030311}$

[10] C. Buabeng-Andoh, "Factors influencing teachers' adoption and integration of information and communication technology into teaching: A review of the literature Charles BuabengAndoh,” Int. J. Educ. Dev. Using Inf. Commun. Technol., vol. 8, no. 1, pp. 136-155, 2012. https://doi.org/10.1007/s10639-020-10267-4

[11] M. Sarwar and T. R. Soomro, "The impact of smartphones on e-participation," Eur. J. Sci. Res., vol. 98, no. 2, pp. 216-226, 2013.

[12] M. R. Mungmachon, "Knowledge and Local Wisdom: Community Treasure," Int. J. Humanit. Soc. Sci., vol. 2, no. 13, pp. 174-181, 2012.

[13] E. Ningrum, Nandi, and D. Sungkawa, "The Impact of Local Wisdom-Based Learning Model on Students' Understanding on The Land Ethic," IOP Conf. Ser. Earth Environ. Sci., vol. 145, p. 12086, 2018. https://doi.org/10.1088/1755-1315/145/1/012086

[14] J. Yuenyong and C. Yuenyong, "Connecting Between Culture of Learning in Thai Contexts and Developing Students' Science Learning in the Formal Setting," Procedia -Social Behav. Sci., vol. 46, pp. 5371-5378, 2012. https://doi.org/10.1016/j.sbspro.2012.06. $\underline{441}$

[15] J. L. Docktor and J. P. Mestre, "Synthesis of discipline-based education research in physics,” Phys. Rev. Spec. Top. - Phys. Educ. Res., vol. 10, no. 2, pp. 1-58, 2014. https:// doi.org/10.1103/physrevstper.10.020119

[16] P. B. Kohl and N. D. Finkelstein, "Student representational competence and selfassessment when solving physics problems," Phys. Rev. Spec. Top. - Phys. Educ. Res., vol. 1, no. 1, pp. 1-11, 2005. https://doi.org/10.1103/physrevstper.1.010104

[17] G. F. M. Sinaga, A. Hartoyo, and Hamdani, "Kemampuan representasi matematis siswa ditinjau dari gaya belajar pada materi fungsi kuadrat di SMA," J. Pendidik. dan Pembelajaran, vol. 5, no. 06, Jun. 2016. https://doi.org/10.21831/pg.v11i2.10655

[18] G. Rizky, D. Tomo, and T. Haratua, "Kemampuan multirepresentasi siswa sma dalam menyelesaikan soal-soal Newton law," J. Pendidik. dan Pembelajaran, vol. 3, no. 8, Aug. 2014. 
[19] N. S. Pratama and E. Istiyono, "Studi Pelaksanaan Pembenlajaran Fisika Berbasis Higher Order Thinking (HOTS) pada Kelas X di SMA Negeri Kota Yogyakrata," Pros. Semin. Nas. Fis. dan Pendidik. Fis., vol. 6, no. 2, Sep. 2015. https://doi.org/10.31540/sipif.v1i1.3 $\underline{20}$

[20] M. Ally, Mobile learning: transforming the delivery of education and training. Canada: AU Press, 2009.

[21] M. L. Crescente and D. Lee, "Critical issues of m-learning: design models, adoption processes, and future trends,” J. Chinese Inst. Ind. Eng., vol. 28, no. 2, pp. 111-123, Mar. 2011.

[22] N. Liliarti and H. Kuswanto, "Improving the Competence of Diagrammatic and Argumentative Representation in Physics through Android-based Mobile Learning Application," Int. J. Instr., vol. 11, no. 3, pp. 106-122, 2018. https://doi.org/10.12973/iji.20 $\underline{18.1138 \mathrm{a}}$

[23] N. Mardiana and H. Kuswanto, "Android-assisted physics mobile learning to improve senior high school students' divergent thinking skills and physics HOTS,” AIP Conf. Proc., vol. 1868, no. 070005, 2017. https://doi.org/10.1063/1.4995181

[24] K. Said, A. Kurniawan, and O. Anton, "Development of media-based learning using android mobile learning," J. Theor. Appl. Inf. Technol., vol. 15, no. 3, pp. 668-676, 2018.

[25] K. Tamhane, W. T. Khan, S. R. Tribhuwan, A. P. Burke, and S. B. Take, "Mobile Learning Application,” Int. J. Sci. Res. Publ., vol. 5, no. 3, 2015.

[26] V. Seangly, Suyoto, and A. J. Santoso, "The Development of Mobile Learning \&quot;Imbuhan\&quot; Grammar Indonesian Language for Cambodian Students,” Int. J. Comput. Sci. Trends Technol., vol. 4, no. 6, pp. 140-144, 2013.

[27] B. Umeogu and O. Ifeoma, "Constructionist Theory of Representation in Language and Communication: A Philosophical Analysis,” Open J. Philos., vol. 2, no. 2, pp. 130-135, 2012. https://doi.org/10.4236/ojpp.2012.22021

[28] T. Nilsen, C. Angell, and L. S. Grønmo, "Mathematical competencies and the role of mathematics in physics education: A trend analysis of TIMSS Advanced 1995 and 2008," Acta Didact. Norge, vol. 7, no. 1, pp. 1-21, Oct. 2013. https://doi.org/10.5617/adno.1113

[29] D. R. Cole, J. Ullman, S. Gannon, and P. Rooney, "Critical thinking skills in the International Baccalaureates 'theory of Knowledge' subject: Findings from an Australian study," Aust. J. Educ., vol. 59, no. 3, pp. 1-18, Nov. 2015. https://doi.org/10.1177/00049 $\underline{44115603529}$

[30] J. D. Williams, How Science Works: Teaching and Learning in the Science Classroom. Chennai: Continuum, 2011.

[31] M. Alfian, "Potensi kearifan Lokal Dalam Pembentukan Jati Diri dan karakter Bangsa," in the 5th International Conference on Indonesian Studies: "Ethnicity and Globalization," 2013, pp. 424-435.

[32] H. Dahles and T. S. Prabawa, "Entrepreneurship in the informal sector. The Case of the Pedicab Drivers of Yogyakarta, Indonesia," J. Small Bus. Entrep., vol. 26, no. 3, pp. 241259, May 2013. https://doi.org/10.1080/08276331.2013.803672

[33] S. Thiagarajan, D. S. Semmel, and M. L. Semmel, Others Instructional Development for Training Teachers of Exceptional Children: A Sourcebook. Bloomington: The Council for Exceptional Children, 1974. https://doi.org/10.1177/001440297504100608 
[34] S. Peter, T. Anderson, and T. Roscoe, "Arrakis: The Operating System as Control Plane," Login: vol. 38, no. 4, pp. 44-47, 2013.

[35] A. A. Kurniawati, S. Wahyuni, and P. D. A. Putra, "Utilizing of Comic and Jember's Local Wisdom as Integrated Science Learning Materials,” Int. J. Soc. Sci. Humanit., vol. 7, no. 1, pp. 47-50, 2017.

[36] M. K. Abadi, E. C. M. Asih, and A. Jupri, "The Development of Interactive Mathematics Learning Material Based on Local Wisdom with .swf Format,” IOP Conf. Ser. J. Phys. Conf. Ser., vol. 1013, pp. 1-6, 20. https://doi.org/10.1088/1742-6596/1013/1/012131

\section{Authors}

Heribertus Didik Kurniawan is a master student in Physics Education at Yogyakarta State University in 2018. heribertus.didik2016@student.uny.ac.id

Heru Kuswanto is Professor in the Department of Physics Education, Faculty of Mathematics and Natural Sciences, Yogyakarta State University, Indonesia. He got his master's degree from Gajahmada University, Indonesia, and Doctoral degree from Université Jean Monnet de Saint Etienne, France.

Article submitted 2019-07-22. Resubmitted 2020-03-30. Final acceptance 2020-07-28. Final version published as submitted by the authors 